
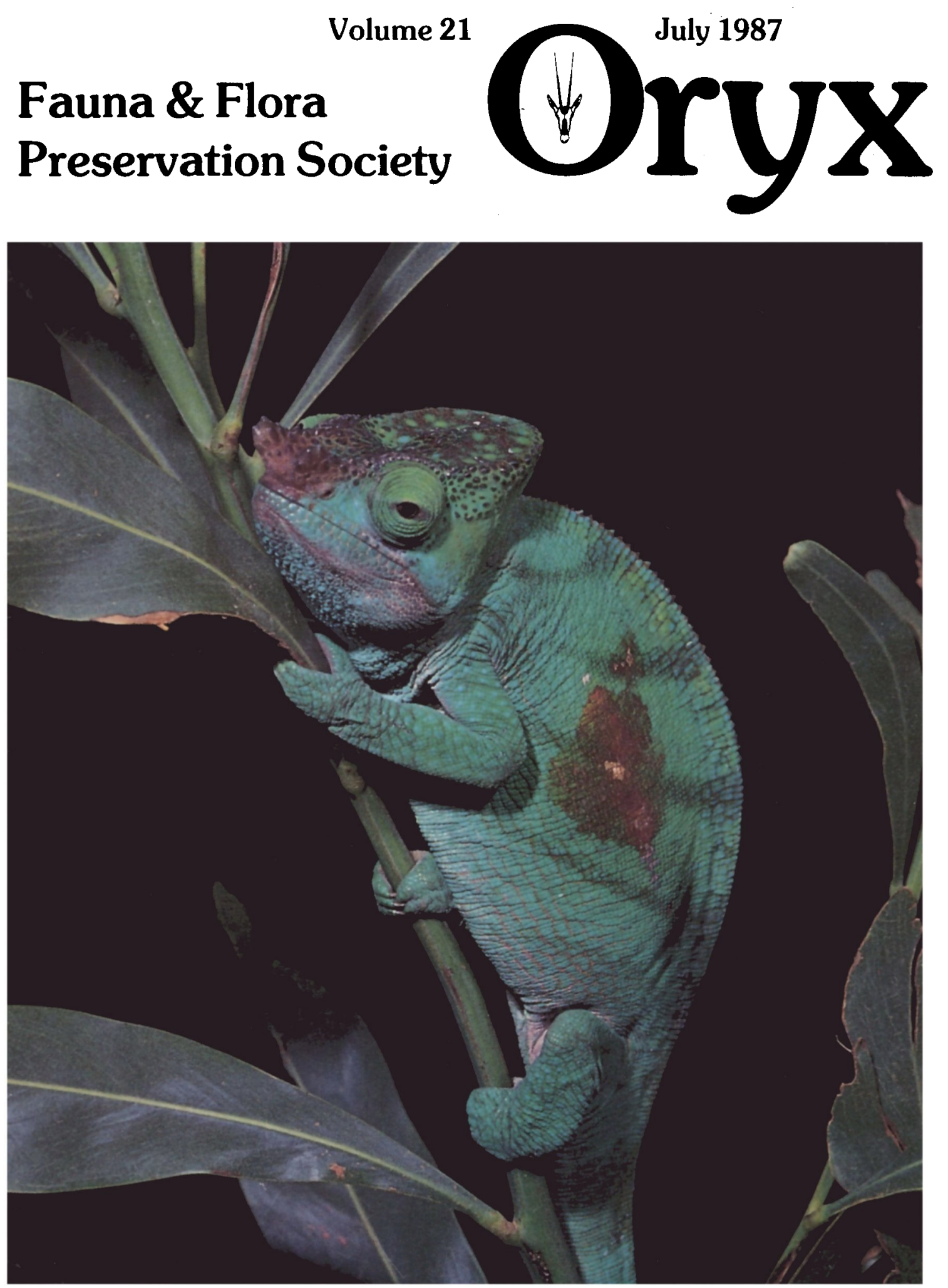


\section{Patron HER MAJESTY THE QUEEN}

Registered address:

c/o Zoological Society of London,

Regent's Park, London NW1 4RY

Address for mail:

8-12 Camden High Street,

London NW1 OJH Tel: 01-3879656

Registered Charity

No. 250358

\section{President}

Sir Peter Scott CBE DSC

Vice-Presidents

Dr E.A.O. Asibey (Ghana)

Sir David Attenborough CBE FRS (UK)

Dr David Bellamy (UK)

Dr Felipe Benavides OBE (Peru)

Lt Col C.L. Boyle OBE (UK)

Dr Gerard A. Bertrand

Mervyn Cowie CBE ED (Kenya)

Lord Craigton, PC, CBE

Dr Kai Curry-Lindahl (Sweden)

Gerald Durrell OBE

Lt Col J.P. Grant of Rothiemurchus, MBE (UK)

Major lan R. Grimwood OBE (Kenya)

Dr Lee M. Talbot (USA)

T.A.P. Walker (UK)

\section{Chairman}

Richard Fitter

Vice-Chairman

David M. Jones
Hon. Treasurer

Edward Hoare

\section{Council}

R.I.J. Agnew

Dr Keith Banister

Stephen Bankler-Jukes

Janet Barber

Lord Birkett

Dr David Chivers

Dr Lee Durrell

Dr S.K. Eltringham

Mrs Maisie Fitter

John Knowles

Professor R.D. Martin

Dr Pat Morris

Dr John Sparks

Dr R.E. Stebbings

Dr lan Swingland

Dr B.A. Thomas

Edward Wright

Fauna \& Flora

Preservation Society Inc.

Directors

Dr Gerard A. Bertrand

Alan D. Hutchison

Dr Alison Jolly

Dr C. Dart Thalman

John Walsh

John A. Burton

Richard Fitter

Hon. Director

Christine Stevens

Executive Director

Duane Pierson
ISSN 0030-6053

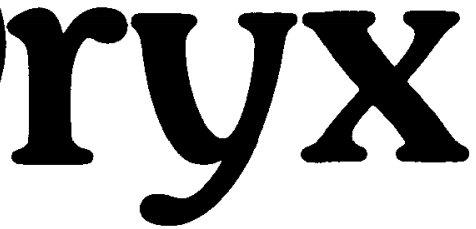

Hon. Photographer

Tim Parmenter

Exec. Secretary

John A. Burton

Editor of Oryx

Dr Jacqui Morris

Manuscripts are invited for consideration for publication and should be sent to the Editor (see inside back cover).

The opinions expressed by authors do not necessarily reflect the policy of FFPS.

Colour cover donated by

Edward Wright Ltd.

Colour separation donated by

Masterlith Ltd of Mitcham in Surrey.

\section{Membership}

Oryx is free to members.

Details, see tear sheet.

Cover: Parson's chameleon

Chamaeleo parsoni, Madagascar (John Visser/Bruce Coleman Ltd).

\section{Subscriptions}

The journal is published quarterly (January, April, July, October) and the subscription price for 1987

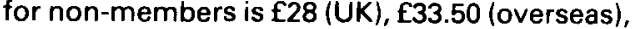
and $\$ 52.50$ (USA, Canada and Japan) post free.

The journal is published for the Fauna \& Flora Preservation Society by Blackwell Scientific Publications Ltd. All matters relating to subscriptions, back numbers and offprints should be sent to Blackwell Scientific Publications Ltd, PO Box 88, Oxford, UK.

\section{Advertising}

Enquiries should be sent to the Advertisement Manager, Blackwell Scientific Publications Ltd, Osney Mead, Oxford OX2 OEL, UK (telephone (0865) 240201; facsimile (0865) 721205).

(C) 1987 Fauna \& Flora Preservation Society.

\section{USA}

Authorization to photocopy items for internal or personal use, or the internal or personal use of specific clients, is granted by the Fauna \& Flora Preservation Society for libraries and other users registered with the Copyright Clearance Center (CCC) Transactional Reporting Service, provided that the base fee of $\$ 03.00$ per copy is paid directly to CCC, 27 Congress Street, Salem, MA 01970, USA. Special requests should be addressed to the Editor. 0030-6053/87\$03.00.

The journal is delivered to North America by accelerated surface post and subscribers there can expect to receive their copies within two weeks of British publication. Second Class postage paid at New York, NY. Postmaster, send address corrections to Oryx, c/o Expediters of the Printed Word Ltd, 515 Madison Avenue, New York, NY 10022. Current issues for the Indian sub-continent, Australasia and the Far East are sent by air to regional distribution points from where they are forwarded to subscribers by surface mail. Any back numbers are normally despatched by surface to all regions, except North America, where they are sent by a.s.p., and India, where they are sent by air freight. 


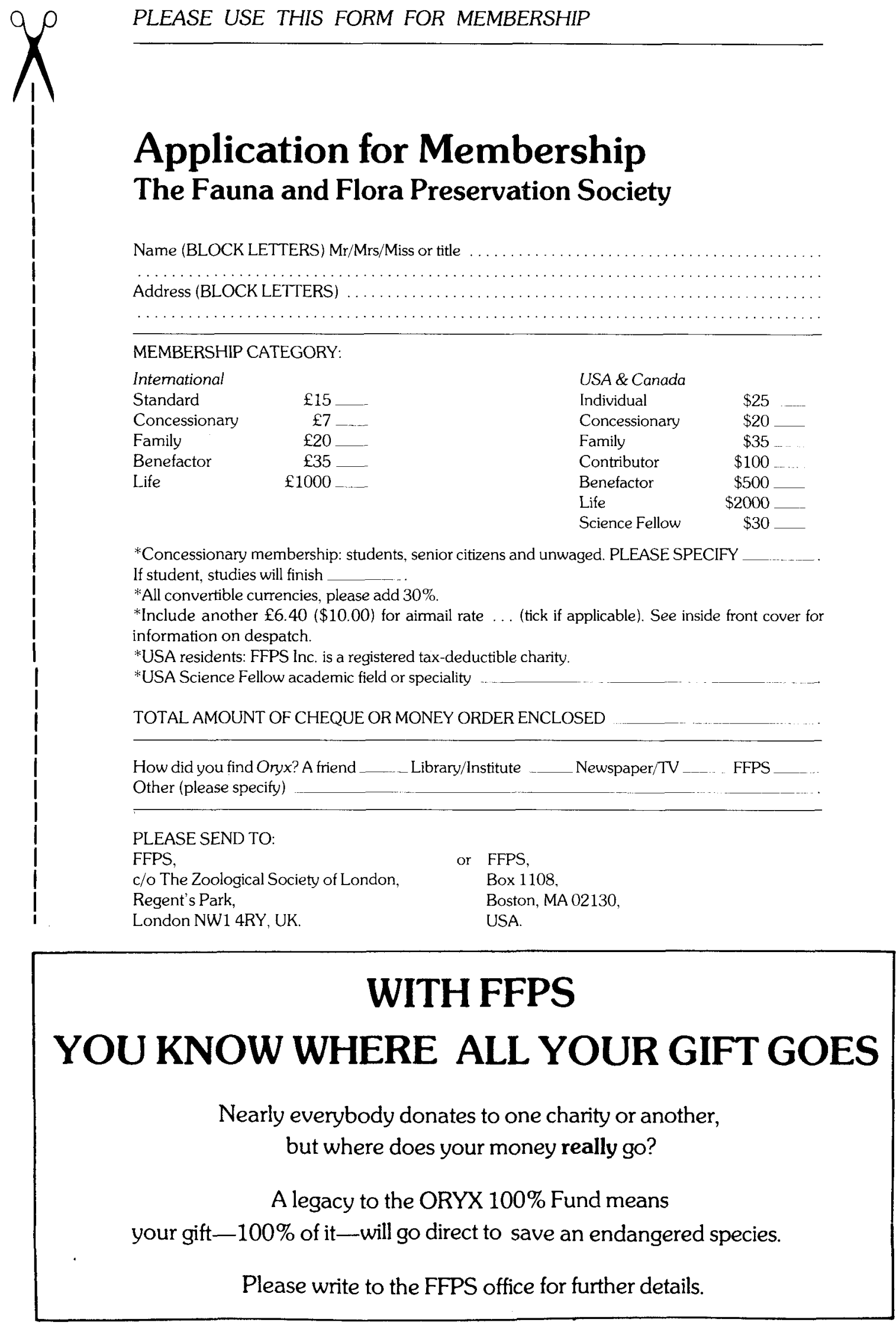




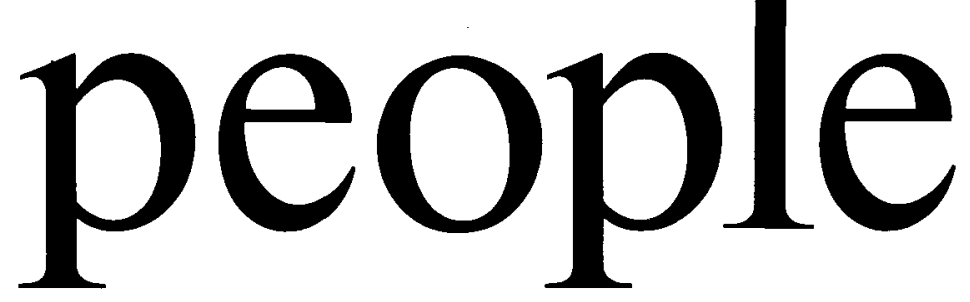

\section{"A quarterly magazine on population and development"}

Published on behalf of the International Planned Parenthood Federation Edited by John Rowley

People reports on worldwide efforts to break the cycle of poverty by linking improvements in nutrition, education, health, employment and living conditions with the planning of childbirth. It does so in human terms, reporting from the villages and shanty towns where the development battles are fought. It looks especially at ways of transforming the productive and reproductive lives of women whose contribution to sustainable development is frequently ignored.

\section{Send for your free copy!}

Recent issues of People have looked at efforts around the world to help people build their own homes and upgrade their environment.

They have also reported on new efforts to bring about safer motherhood in countries where maternal death rates remain high. Write now for subscription details and receive the next issue free!

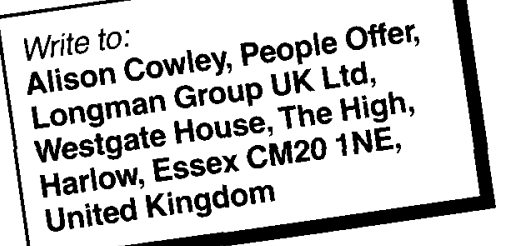



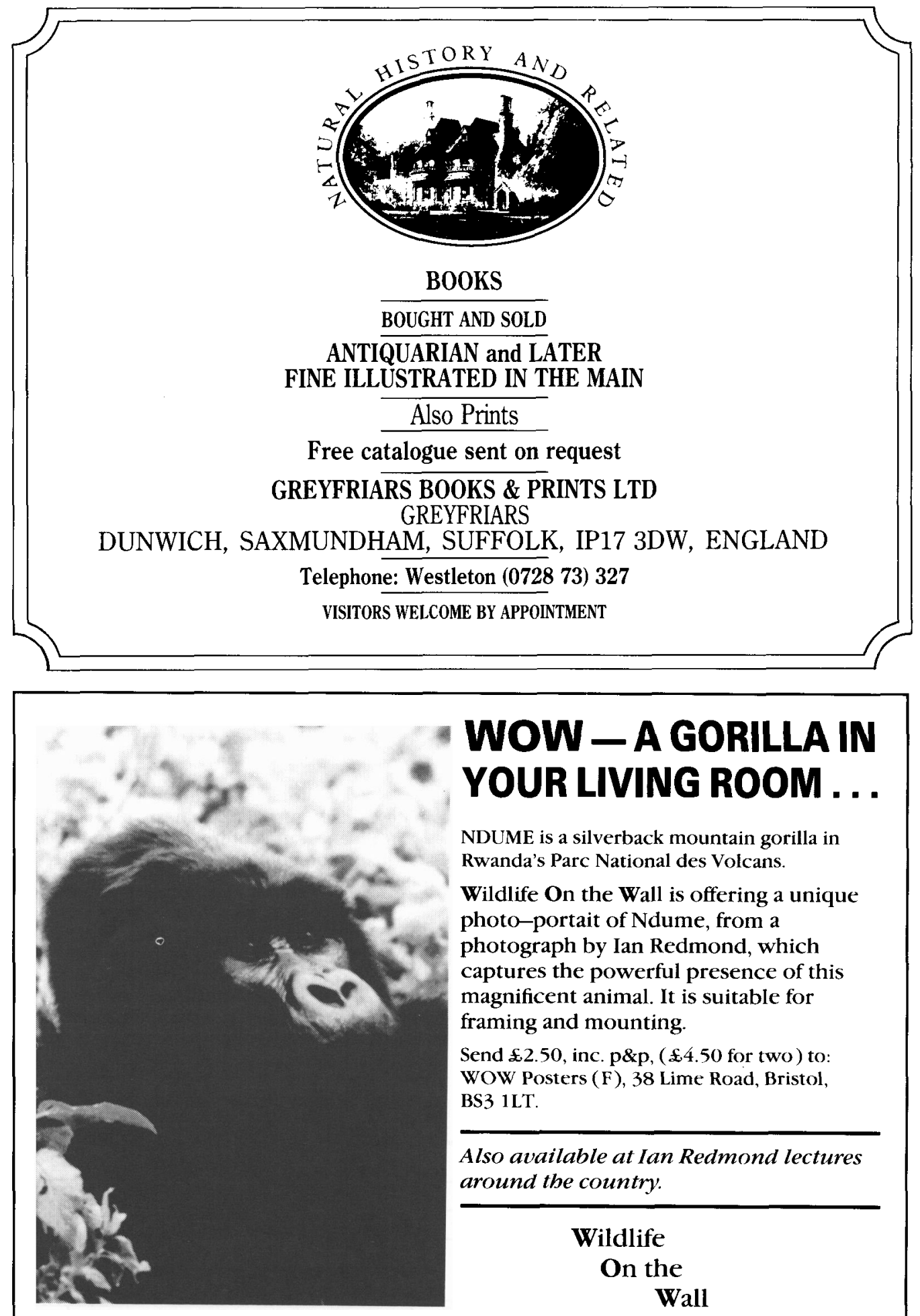

\section{WOW - A GORILLA IN YOUR LIVING ROOM . . .}

NDUME is a silverback mountain gorilla in Rwanda's Parc National des Volcans.

Wildlife On the Wall is offering a unique photo-portait of Ndume, from a photograph by Ian Redmond, which captures the powerful presence of this magnificent animal. It is suitable for framing and mounting.

Send $£ 2.50$, inc. p\&p, ( $£ 4.50$ for two ) to: WOW Posters (F), 38 Lime Road, Bristol, BS3 1LT.

Also available at Ian Redmond lectures around the country.

Wildlife

On the

\section{Wall}

Actual size $22^{\prime \prime} \times 17^{1 / 2 "}$ * Full colour $\star$ Quality paper. Posters, Cards and Educational Displays. 


\section{ASTOR'S GREENLAND ADVENTURE WILL GET YOU EVEN CLOSER TO NATURE.}

IN ASSOCIATION WITH BBC WILDLIFE MAGAZINE

(n the 30th July, Astor sails from Edinburgh on an exciting adventure cruise to Greenland. On board will be Lars-Eric Lindblad, pioneer of travel to the more remote parts of the world, together with Robert Burton, well-known natural history writer and expert on Greenland and the Polar regions, arranged in association with BBC Wildlife magazine.

Some of the world's most breathtaking scenery awaits you. The huge bird colonies of the Shetlands and the Faroes; the volcanoes and geysers of Iceland; and the ice age world of Greenland with its icebergs, glaciers and mountains.

Undisturbed by man, this is the home of polar bears, arctic foxes, musk-ox, snowy owls, sea eagles, puffins and killer whales.

You can even venture forth from Astor's five star luxury on complimentary trips in the ship's inflatables for a closer look at the superb flora and fauna. And all in the long, warm days of the Arctic summer.

Astor will also be cruising to the Norwegian fjords, Spitzbergen and Canada this summer. And we're offering you free travel direct to Edinburgh: by air from selected regional airports or by first class rail from anywhere in the UK.

To find out more about Astor's Greenland "Wildlife" cruise and her other Arctic adventures, just fill in the coupon below and send it today.

Please send me the Astor Cruises brochure and "Wildlife" Information.

Name

Address: 